\title{
Ammonia production, ammonia absorption, and urea recycling in ruminants. A review
}

\author{
Z. $\operatorname{Tan}^{1}$ and M.R. Murphy ${ }^{2}$ \\ ${ }^{1}$ Institute of Subtropical Agriculture, Chinese Academy of Sciences \\ Changsha, Hunan 410125, P.R. China \\ ${ }^{2}$ Department of Animal Sciences and Division of Nutritional Sciences, University of Illinois \\ Urbana 61801,USA
}

(Received 25 February 2004; accepted 16 June 2004)

\begin{abstract}
Relevant research on ammonia production, ammonia absorption, and urea recycling in ruminants was reviewed. Ammonia production and utilization in the rumen and post-ruminal digestive tracts are described in detail. Absorption of ammonia into portal-drained viscera, ammonia detoxification and urea synthesis in the liver, and urea degradation in the gastrointestinal tract are then discussed. The factors of affecting urea recycling and its pathways are also analysed. Suggested future research should focus on urea recycling dynamics and improvement of protein conversion efficiency, and on the development of an integrated mechanistic model to describe the digestion and metabolism of nitrogen-containing compounds in ruminants fed practical diets.
\end{abstract}

KEY WORDS: ammonia, urea, recycling, ruminant

\section{INTRODUCTION}

Ammonia and urea, in addition to amino acids (AA), peptides and microbial crude protein (MCP), etc., play an important role in nitrogen digestion and metabolism in ruminants. The feeding of non-protein nitrogen (NPN) supplements to ruminants is based on the knowledge that $\mathrm{NH}_{3}$ is the major end-product of protein degradation in the rumen and on the belief, which appears to have been generally accepted, that most of the $\mathrm{N}$ utilized by rumen microbes comes from the $\mathrm{NH}_{3}$ pool in the rumen (Nolan and Leng, 1972). Ruminants have been maintained on

\footnotetext{
${ }^{1}$ Corresponding author: e-mail: zltan@isa.ac.cn
} 
diets in which the only source of nitrogen was either $\mathrm{NH}_{3}$ salts or urea, indicating that all of the AA that are essential for nonruminants can be synthesized by ruminal microorganisms. In ruminants, urea is an end product of $\mathrm{N}$ metabolism, but bacteria have the enzymatic capability to hydrolyze urea, thereby making urea-N available as $\mathrm{NH}_{3}$. The objective of this paper is to focus on certain aspects of urea recycling that have been reported and to relate these to their potential nutritional significance in ruminants.

\section{GENERAL OVERVIEW OF $\mathrm{NH}_{3}$ PRODUCTION AND UREA RECYCLING}

It is first necessary to understand the complex and dynamic process of $\mathrm{N}$ digestion and metabolism in ruminants. Usually, ruminants are much less efficient than nonruminants in utilizing high quality dietary proteins. A dominant feature of $\mathrm{N}$ digestion and metabolism is microbial conversion of some dietary protein to $\mathrm{NH}_{3}$ in ruminants. Dietary intake protein (IP) is either degraded (DIP) in the rumen, with partial or total conversion to MCP, or passed from the rumen as undegradable intake protein (UIP). The DIP provides peptides, $\mathrm{AA}$, and $\mathrm{NH}_{3}$ to satisfy microbial requirements. In ruminants, $\mathrm{NH}_{3}-\mathrm{N}$ concentrations in the rumen usually surpass the practical requirements for microbial growth in the rumen; therefore, excess $\mathrm{N}$ is absorbed as $\mathrm{NH}_{3}$ and converted to urea by the liver. Urea synthesized in the liver can diffuse into the rumen, small intestine, and hindgut, or be secreted in saliva for utilization by ruminal microbes. Urea is also excreted by the kidneys and present in other secretions.

\section{AMMONIA PRODUCTION AND LOSS IN THE GASTROINTESTINAL TRACT}

Ruminants absorb substantial amounts of their dietary $\mathrm{N}_{\text {as }} \mathrm{NH}_{3}$ and, for many diets, more $\mathrm{N}$ is absorbed as $\mathrm{NH}_{3}$ than as $\alpha$-amino $\mathrm{N}$ (Reynolds, 1992). Ammonia generation in the gut results from two main processes: one is microbial degradation of nitrogenous compounds within the gut lumen, the other is microbial hydrolysis of urea passing across the gut wall from the blood and intestinal fluids (Parker et al., 1995). The primary source of $\mathrm{NH}_{3}$ within the rumen is dietary protein, except for ruminants consuming diets very low in protein. The UIP and indigestible intake protein (IIP) usually pass to the duodenum without affecting $\mathrm{NH}_{3}$ production in the rumen. Degradable dietary NPN can be converted rapidly and quantitatively to $\mathrm{NH}_{3}$, dissolved nucleic acids in the rumen are also degraded extensively (Leng and Nolan, 1984) by rapid action of bacterial peptidases and deaminases to produce $\mathrm{NH}_{3}$. In addition, endogenous non-urea $\mathrm{N}$ and endogenous urea contribute to $\mathrm{NH}_{3}$ sources of endogenous fermentable protein include sloughed mucosal cells and salivary proteins. Nolan (1975) indicated that $4.4 \mathrm{~g}$ of $\mathrm{NH}_{3}-\mathrm{N}$ per day were produced from these endogenous sources in sheep. Endo- 
genous urea can also serve as a significant source of $\mathrm{NH}_{3}$ in the rumen after either passing from blood plasma into the rumen or being swallowed in saliva (Leng and Nolan, 1984). Other routes of $\mathrm{NH}_{3}$ production in the rumen include $\mathrm{NH}_{3}$ derived from protozoa and fixation of atmospheric $\mathrm{N}_{2}$, although the latter is apparently negligible (Li Pun and Satter, 1975).

Routes of $\mathrm{NH}_{3}$ loss from the rumen pool include $\mathrm{NH}_{3}-\mathrm{N}$ incorporated into microbial cells, $\mathrm{NH}_{3}$ outflow and $\mathrm{NH}_{3}$ absorption. Al-Dehneh et al. (1997) noted that endogenous urea- $\mathrm{N}$ contributed 19.1 and $37.5 \%$ of the $\mathrm{N}$ in duodenal digesta and duodenal bacteria for lactating cows. Outflows of $\mathrm{NH}_{3}$ depend on its concentration in the rumen and the fractional rate of fluid outflow. Duodenal $\mathrm{NH}_{3}$ flow measured in cows and sheep represented 2 and $9 \%$ of $\mathrm{N}$ intake, respectively (Firkins et al., 1987; Song and Kennedy, 1989). $\mathrm{NH}_{3}$ absorption from the rumen is mainly a function of the ruminal concentration of $\mathrm{NH}_{3}$ and is also the primary pathway of $\mathrm{NH}_{3}$ loss from the rumen. Absorption does not appear to be by active transport but occurs via passive non-ionic diffusion down a concentration gradient (Parker et al., 1995). High concentrations of ruminal $\mathrm{NH}_{3}$ increase the flux of $\mathrm{NH}_{3}$ into the blood. Diffusion of $\mathrm{NH}_{3}$ across the rumen wall has been demonstrated in vivo and in vitro (Siddons et al., 1985; Bödeker et al., 1990; Rémond et al., 1993). Under normal physiological conditions, most of the $\mathrm{NH}_{3}$ in the gut lumen will be in the ionized form because its $\mathrm{pH}$ ranges from 2 to 6 .

Usually, concentrations of $\mathrm{NH}_{3}$ in hind-gut digesta are substantial. The $\mathrm{NH}_{3}$ in the post-ruminal digestive tract includes $\mathrm{NH}_{3}$ outflow from the reticulorumen, $\mathrm{NH}_{3}$ from deaminated $\mathrm{AA}$, and $\mathrm{NH}_{3}$ from hydrolysed endogenous urea. Of these, much of the $\mathrm{NH}_{3}$ comes from endogenous urea $\mathrm{N}$ in the post-ruminal digestive tract. Routes of $\mathrm{NH}_{3}$ loss include incorporation of $\mathrm{NH}_{3}$ into MCP, absorption of $\mathrm{NH}_{3}$, and elimination in faeces. Rémésy and Demigné (1989) found that $\mathrm{NH}_{3}$ absorption from the caecum was increased in rats fed diets containing fermentable carbohydrates. Parker et al. (1995) concluded that this may in part be due to the increased entry of urea into the caecum and its hydrolysis by the caecal flora, it is also possible that the increased concentration of VFA in the caecal digesta had a more direct effect on $\mathrm{NH}_{3}$ flux across the caecal wall. Meanwhile, it is also possible that bicarbonate has the ability to stimulate colonic $\mathrm{NH}_{3}$ absorption in ruminants. Usually, bacteria in the digestive tract utilize $\mathrm{NH}_{3}$ as their preferred source of $\mathrm{N}$, and other forms of protein or AA are reduced to $\mathrm{NH}_{3}$ before being used metabolically (Jackson, 1995).

\section{UREA RECYCLING}

Urea recycling is significantly related to $\mathrm{NH}_{3}$ production and absorption in the gastrointestinal tract (GIT) of ruminants. All $\mathrm{NH}_{3}$ absorbed from the rumen epithelium, small intestinal mucosa, and large intestinal mucosa travels via the portal 
vein to the liver; body tissue $\mathrm{NH}_{3}$ also enters the liver. Liver metabolism has a central role in the integration of body $\mathrm{N}$ metabolism. Ammonia in the liver is detoxified by conversion to urea, urea can then be recycled directly into the rumen, small intestine, or large intestine; it can enter the rumen in saliva, be excreted by the kidney, or be secreted in milk or sweat (Alio et al., 2000).

Although portal absorption rates provide an overall measure of $\mathrm{NH}_{3}$ flux into the blood, a number of different techniques have been used to study the relative contribution of different sections of the digestive tract to total $\mathrm{NH}_{3}$ absorption by PDV (Parker et al., 1995). Siddons et al. (1985) provided a dynamic model of $\mathrm{NH}_{3}-\mathrm{N}$ transfer across different sections of the digestive tract. Seal and Reynolds (1993) probed the relationship between $\mathrm{NH}_{3}$ flux in portal blood and dietary $\mathrm{N}$ intake; they found that portal $\mathrm{NH}_{3}$ flux can represent as much as 0.65 of $\mathrm{N}$ intake and in many circumstances can exceed net $\alpha-\mathrm{NH}_{2}-\mathrm{N}$ absorption into portal blood. The $\mathrm{NH}_{3}$ flux from different sections of the gastrointestinal tract can be measured using chronically-catheterized animals. Body tissue $\mathrm{NH}_{3}$ flux into the liver can then be deduced, provided that the overall rate of urea synthesis from $\mathrm{NH}_{3}$ is known.

\section{HEPATIC DETOXIFICATION OF $\mathrm{NH}_{3}$, UREA SYNTHESIS AND REMOVAL}

Ammonia is extremely toxic in non-hepatic tissues, causing changes in cerebral metabolism that can result in tetany and death when circulating concentrations exceed $0.7 \mathrm{mM}$ (Symonds et al., 1981). Under normal physiological and nutritional conditions, $\mathrm{NH}_{3}$ absorbed into the portal vein is efficiently extracted by the liver and detoxified by conversion to urea or glutamine. Over a wide range of portal $\mathrm{NH}_{3}$ concentrations and on a variety of diets, the liver is able to extract 70 to $95 \%$ of portal $\mathrm{NH}_{3}$. As a result, hepatic $\mathrm{NH}_{3}$ removal is on average slightly higher (4\%) than portal absorption. Thus, arterial $\mathrm{NH}_{3}$ concentrations remain relatively constant even when portal $\mathrm{NH}_{3}$ absorption varies threefold (Parker et al., 1995). This ensures that any $\mathrm{NH}_{3}$ which escapes conversion to urea in periportal hepatocytes is converted to glutamine in perivenous hepatocytes. Amide-N of glutamine is then removed and metabolized to urea by periportal hepatocytes during subsequent passages through the liver, and may also provide a mechanism to avoid a decrease in extracellular pH (Haussinger et al., 1992). Havassy et al. (1982) and Kowalczyk et al. (1982) found that urea nitrogen in the rumen was fixed transiently into plasma protein. Enrichment of ${ }^{15} \mathrm{~N}$ of the bacterial matter and plasma protein exceeded that of individual amino acid indicating that urea nitrogen was utilized to a large extent for the synthesis of nitrogen compounds other than amino acids. Maltby et al. (1991, 1993b) reported that when urea was added to ruminant diets there was increased hepatic $\mathrm{NH}_{3}$ uptake but glutamine uptake was either unchanged or slightly increased; however, net hepatic output of glutamate was decreased. The conversion of $\mathrm{NH}_{3}$ to glutamine and glutamate 
is not a major detoxification pathway under normal feeding conditions. Lobley et al. (1995) reported that 93.5 and $6 \%$ of portal ${ }^{15} \mathrm{NH}_{4} \mathrm{Cl}$ is converted to ${ }^{15} \mathrm{~N}$-urea and ${ }^{15} \mathrm{~N}$-glutamine, respectively, when portal vein $\mathrm{NH}_{3}$ concentrations were increased to $0.5 \mathrm{mM}$ by intramesenteric vein infusion in sheep. The capacity of ruminant liver to remove $\mathrm{NH}_{3}$ is apparently 1.2 to $1.5 \mu \mathrm{mol} / \mathrm{min}$ per gram (Symonds et al., 1981) and the potential contribution of extracted $\mathrm{NH}_{3}-\mathrm{N}$ to hepatic urea- $\mathrm{N}$ formation ranges from 27 to $110 \%$. Reasons for variation in the contribution of $\mathrm{NH}_{3}$ to hepatic urea production are not clear, but Parker et al. (1995) considered the large range not to be an artifact and noted that animal factors and intake appeared not to be implicated. The major route of urea entry from blood to the rumen is via saliva.

\section{UREA DEGRADATION IN THE RETICULORUMEN AND POST-RUMINAL DIGESTIVE TRACTS}

Substantial amounts of recycled urea-N can be used by bacteria in the lumen of the gut for metabolic needs or reabsorbed as $\mathrm{N}$ in the forms of AA, nucleic acids, or $\mathrm{NH}_{3}$ (Kowalczyk et al., 1975a; Nolan and Stachiw, 1979; Huntington, 1989; Reynolds, 1992). This provides a mechanism for salvage of urea-N by conversion into bacterial matter that can then be digested, yielding AA for use by the host (Sarraseca et al., 1998). Jackson (1995) concluded that urea-N retained in the body might, in principle, be converted into AA-N in one of four ways: absorbed as $\mathrm{NH}_{3}$ and fixed in the liver through amination to form non-essential AA, e.g., as glutamate or glycine-serine; through wider transamination with the $\mathrm{C}$ skeleton of a transaminating non-essential AA, e.g., alanine and aspartate; through wider transamination with the $\mathrm{C}$ skeleton of a transaminating essential AA; by bacterial synthesis of an essential or non-essential AA.

The amount of urea- $\mathrm{N}$ transferred into the rumen is determined by the rate of salivary secretion and by the plasma urea concentration. Nolan and MacRae (1976) reported that $5.3 \mathrm{~g}$ of blood urea-N/d entered the digestive tract of sheep; $20 \%$ of this urea was degraded in the rumen, $25 \%$ in the caecum, and the remainder was apparently degraded elsewhere. There was evidence of urea degradation in the large intestine posterior to the caecum, and it was suggested that urea degradation and absorption of the synthesized $\mathrm{NH}_{3}$ might also occur in the ileum.

Kowalczyk et al. (1975a,b) stated that only a small amount of blood urea nitrogen was utilized for microbial synthesis in the rumen, and the greatest part of postruminal endogenous nitrogen was reabsorbed during passage of digesta through the intestine (Sandek et al., 2002). Norton et al. (1978) noted that an average of $81 \%$ of the urea synthesized in the body was transferred to the digestive tract and degraded to $\mathrm{NH}_{3}$ and carbon dioxide. Endogenous urea degraded in the rumen accounted for 7 to $13 \%$ of the total quantity degraded in the digestive tract, and the rate of urea transfer was not related to the rate of urea synthesis 
in the body. The lower digestive tract was the major site of urea degradation in sheep given low protein diets, and the rate of urea transfer to this part of the digestive tract was linearly related to the rate of urea synthesis in the body. Koenig et al. (2000) and Newbold et al. (2000) reported that urea-N contributed 20\% of rumen $\mathrm{NH}_{3}$ flux in sheep offered either a forage-concentrate ration or pelleted dried grass, respectively. It was concluded that urea transferred from the blood to the reticulo-rumen and the hind gut is degradable, making $\mathrm{NH}_{3}-\mathrm{N}$ available for use by microorganisms or for reabsorption and utilization by the body.

\section{FACTORS AFFECTING UREA RECYCLING}

All factors that influence the production, absorption, and transfer of $\mathrm{NH}_{3}$ and urea will affect urea recycling in ruminants. Kennedy and Milligan (1980) reported that urea transfer to the rumen was inversely related to the rumen $\mathrm{NH}_{3}$ concentration, and suggested that the $\mathrm{NH}_{3}$ concentration was a factor regulating urea entry into the rumen. There was a marked reduction of urea transfer to the rumen when the ruminal $\mathrm{NH}_{3}$ concentration was elevated by continuous $\mathrm{NH}_{3}$ infusion into it. Rémond et al. (1993) concluded that $\mathrm{NH}_{3}$ absorption seems to be mainly influenced by the $\mathrm{NH}_{3}$ concentration in the rumen fluid, and by the rate of VFA absorption. $\mathrm{Net}_{\mathrm{NH}_{3}}$ flux across the rumen wall is linearly related to both free $\mathrm{NH}_{3}$ and to total $\mathrm{NH}_{3}$ concentrations. Additionally, ruminal VFA may stimulate the uptake of $\mathrm{NH}_{3}$. Bödeker et al. (1992) found that $\mathrm{NH}_{3}$ absorption was stimulated by the presence of VFA in the mucosal buffer solution, either individually or as a mixture of acetate, propionate, and butyrate. Similar responses to additional butyrate on transfer of $\mathrm{NH}_{3}$ into the ruminal vein of sheep have also been reported (Rémond et al., 1993).

Tracer studies have indicated that a supplemental energy source such as grain, starch, or dried beet pulp, significantly increased endogenous urea degradation in the gastrointestinal tract. It is possible that the rumen was the site of increased degradation because Kennedy and Milligan (1980) reported that dietary sucrose greatly enhanced the rate of transfer of urea to the rumen. Huntington and Reynolds (1986) pointed out that the effects of dietary energy density or fermentability of a substrate in the rumen on the rate and site of endogenous urea transfer to the gut were obvious.

On the other hand, urea transfer from blood to the GIT might not be controlled by the urea concentration in plasma alone. In sheep and cattle, the upper limits of the blood urea concentration above which urea transfer was no longer linearly related to plasma urea concentrations were $6.0 \mathrm{mM}$ and $4.0 \mathrm{mM}$, respectively. Elevation of plasma urea above these concentrations did not further increase rumen $\mathrm{NH}_{3}$. Norton et al. (1978) found that transfer of urea into the post-ruminal tract is correlated with both plasma urea concentration and its production rate. 
Feed intake is an important factor that influences the return of urea to the GIT. Bunting et al. (1989) reported that net incorporation of blood urea-N into bacterial protein is inversely related to the protein intake of calves. Sarraseca et al. (1998) found that urea- $\mathrm{N}$ production in sheep increased with intake and exceeded digestible $\mathrm{N}$ at all intakes. Urea- $\mathrm{N}$ entering the digestive tract that was returned to the ornithine cycle remained constant across intakes but the absolute amount increased with $\mathrm{N}$ intake. Urea removed by the PDV, unaffected by intake, represented 32, 33, and $21 \%$ of the digested N. Meanwhile the reabsorption of endogenous nitrogen was significantly influenced by the dietary crude fibre level for growing sheep (Sandek et al., 2002).

Leng and Nolan (1984) reported that $\mathrm{NH}_{3}$ concentrations in rumen fluid were positively correlated with the number of ciliate protozoa, and $\mathrm{NH}_{3}$ concentrations in the rumen fluid of defaunated animals were lower than in those with protozoa. The absorption of $\mathrm{NH}_{3}$ is also likely to be lower in defaunated animals. Additionally, Allan and Miller (1976) found that, at equal rates of urea production, lambs tended to maintain higher plasma urea concentrations and greater rates of urea degradation in the GIT than did wethers; urea degradation was related to plasma urea concentrations in lambs but not in wethers.

Lastly, there are other factors that can also influence urea recycling for ruminants, such as physiological conditions, osmolality in the GIT, gastrointestinal hormones, etc. (Kennedy and Milligan, 1980). Bödeker et al. (1991) found that $\mathrm{HCO}_{3}^{-}$favoured $\mathrm{NH}_{3}$ absorption across the ruminal epithelium and Rémond et al. (1993) noted that $\mathrm{CO}_{2}$ insufflation resulted in a $16 \%$ increase in net transfer of $\mathrm{NH}_{3}$ across the ruminal wall. Although blood flow to the sheep rumen was increased, increased osmolality after $\mathrm{NaCl}$ injection slightly decreased $\mathrm{NH}_{3}$ absorption.

\section{RESEARCH APPROACHES}

Two approaches are often used to study the recycling of nitrogen-containing compounds. One involves use of labelled isotope tracers and the other employs chronic catheterization of venous and arterial vessels.

\section{Single or continuous isotope tracer technique}

First, it is necessary to assume that the animal is in a steady state; i.e. pool sizes remain constant and the rates of inflow and outflow are equal. Isotope tracer techniques generally include both single infusion and continuous infusion methods. Most of the metabolic studies made with ${ }^{15} \mathrm{~N}$ have used single infusion rather than continuous infusion methods.

Analysis of isotope ratio with time yield curves for various primary compartments. The change in isotope ratio $\left(\mathrm{Y}_{\mathrm{t}}\right)$ in a primary pool with time after a single injection of an isotope tracer is given by a multi-exponential curve of the form: 


$$
\mathrm{Y}_{\mathrm{t}}=\sum_{I=1}^{n} \mathrm{~A}_{\mathrm{i}} \mathrm{e}^{-\mathrm{m}}{ }_{\mathrm{i}}^{{ }_{\mathrm{t}}}
$$

where $\mathrm{t}=$ time, $\mathrm{A}_{\mathrm{i}}={ }^{15} \mathrm{~N}$-enrichment in the corresponding pool at the zero-time intercept of the $\mathrm{i}^{\text {th }}$ compartment, $\mathrm{m}_{\mathrm{i}}=$ the fractional rate constant for the $\mathrm{i}^{\text {th }}$ compartment, $\mathrm{n}=$ the number of exponential compartment, $\mathrm{i}=$ the exponential compartment number, and $\mathrm{Y}_{\mathrm{t}}={ }^{15} \mathrm{~N}$-enrichment in the corresponding pool at time $\mathrm{t}$.

Parameter estimates from the fitted equations are then used to calculate ruminal $\mathrm{NH}_{3}-\mathrm{N}$ pool size, total entry rate or flux, irreversible loss, and recycling. The relevant equations are as follows:

$$
\begin{aligned}
& \mathrm{Q}=\mathrm{D} / \sum_{I=1}^{n} \mathrm{~A}_{\mathrm{i}} \\
& \mathrm{F}=\mathrm{Q}\left\{\sum_{I=1}^{n} \mathrm{a}_{\mathrm{i}} \mathrm{m}_{\mathrm{i}}\right\} \\
& \mathrm{a}_{\mathrm{i}}=\mathrm{A}_{\mathrm{i}} / \sum_{I=1}^{n} \mathrm{~A}_{\mathrm{i}} \\
& \mathrm{L}=\mathrm{D} /\left\{\sum_{I=1}^{n} \mathrm{~A}_{\mathrm{i}} / \mathrm{m}_{\mathrm{i}}\right\} \\
& \mathrm{R}=\mathrm{F}-\mathrm{L}
\end{aligned}
$$

where $\mathrm{Q}=$ pool size, $\mathrm{D}=$ dose of ${ }^{15} \mathrm{~N}, \mathrm{~F}=$ total flux rate, $\mathrm{a}_{\mathrm{i}}$ is the fractional zerotime intercept of component $\mathrm{A}_{\mathrm{i}}, \mathrm{L}=$ irreversible loss rate, $\mathrm{R}=$ recycling rate.

The quantity of urea synthesized in the body, degraded to $\mathrm{NH}_{3}$ in the digestive tract, and subsequently resynthesized into urea by the body can be estimated from the difference between the rates of irreversible loss of urea-C and urea- $\mathrm{N}$ from plasma, as estimated by using simultaneous injection of ${ }^{14} \mathrm{C}$-urea and ${ }^{15} \mathrm{~N}$-urea. This is possible because ${ }^{14} \mathrm{C}$ from hydrolysed urea enters a very large bicarbonate pool with a rapid turnover; therefore, the return of ${ }^{14} \mathrm{C}$ into newly synthesized urea is negligible (Koenig et al., 2000). As for the continuous injection method, the irreversible loss rate of $\mathrm{NH}_{3}$ from ruminal fluid is calculated by comparing enrichment of $\mathrm{NH}_{3}$ at "plateau" enrichment with the rate of infusion of ${ }^{15} \mathrm{~N}$ ammonium sulphate. The proportion of urea in plasma, or the bacteria- $\mathrm{N}$ in the ruminal fluid derived from this, is calculated as the ratio of the "plateau" enrichments of urea-N or bacteria- $\mathrm{N}$ to $\mathrm{NH}_{3}-\mathrm{N}$.

Recently, a different isotope tracer technique has been developed (Sarraseca et al., 1998). This method involves infusion of $\left({ }^{15} \mathrm{~N}^{15} \mathrm{~N}\right)$-urea, followed by isotope analysis of three species $\left({ }^{15} \mathrm{~N}^{15} \mathrm{~N}\right),\left({ }^{14} \mathrm{~N}^{15} \mathrm{~N}\right)$ and $\left({ }^{14} \mathrm{~N}^{14} \mathrm{~N}\right)$. The technique is based on the assumption that when urea enters the GIT as a $\left({ }^{15} \mathrm{~N}^{15} \mathrm{~N}\right)$ molecule and then undergoes hydrolysis via bacterial urease action, this will yield two molecules of ${ }^{15} \mathrm{NH}_{3}$. If these ${ }^{15} \mathrm{NH}_{3}$ molecules are then reabsorbed and extracted by the liver then they may com- 
bine with ${ }^{14} \mathrm{~N}$ atoms (from aspartate) within the hepatic ornithine cycle to yield two $\left({ }^{15} \mathrm{~N}^{14} \mathrm{~N}\right)$-urea molecules. The chances of $\left({ }^{15} \mathrm{~N}^{15} \mathrm{~N}\right)$-urea returning to the system after entry to the gut, whether directly or indirectly by combination of two ${ }^{15} \mathrm{~N}$-containing molecules within the ornithine cycle, are considered negligible.

\section{Arterial-venous difference techniques}

This technique requires precise surgical interventions, liver and GIT metabolism can be separated and the latter can be further separated via careful catheterization; accurate determination of blood flows is required. Chronic catheters are usually inserted into the hepatic vein, the portal vein, a mesenteric vein, the ruminal vein and a jugular artery. Rates of $\mathrm{NH}_{3}$ absorption and urea synthesis can be estimated but data on the fate of urea-N are not (Table 1). According to Table 1 , the following relationships can be obtained between $\mathrm{N}$ intake $\left(\mathrm{x}_{1}\right.$ in $\mathrm{g}$ per day) or portal $\mathrm{NH}_{3}$ absorption ( $\mathrm{x}_{2}$ in mmol per min) and hepatic urea synthesis ( $\mathrm{y}$ in mmol per min):

$$
\begin{array}{clll}
\text { Cattle: } & \mathrm{y}=-116.8+2.94 \mathrm{x}_{1}, & \mathrm{r}^{2}=0.77, & \mathrm{n}=20 \\
& \mathrm{y}=13.0+1.53 \mathrm{x}_{2}, & \mathrm{r}^{2}=0.77, & \mathrm{n}=20 \\
\text { Cow: } & \mathrm{y}=1171.8-1.08 \mathrm{x}_{1}, & \mathrm{r}^{2}=0.26, & \mathrm{n}=4 \\
& \mathrm{y}=-143.0+1.72 \mathrm{x}_{2}, & \mathrm{r}^{2}=0.88, & \mathrm{n}=4 \\
\text { Sheep: } & \mathrm{y}=29.0+0.60 \mathrm{x}_{1}, & \mathrm{r}^{2}=0.06, & \mathrm{n}=10 \\
& \mathrm{y}=11.1+1.23 \mathrm{x}_{2}, & \mathrm{r}^{2}=0.10, & \mathrm{n}=10
\end{array}
$$

It was concluded that significant relationships exist between dietary $\mathrm{N}$ intake or portal $\mathrm{NH}_{3}$ absorption and hepatic urea synthesis in cattle. In sheep, much weaker relationships are noted between $\mathrm{N}$ intake or portal $\mathrm{NH}_{3}$ absorption and hepatic urea synthesis.

\section{MANIPULATING PATHWAYS OF UREA RECYCLING}

In ruminants, especially those in developing countries, protein nutrition becomes more important because protein resources are limited. In developed countries $\mathrm{N}$ in urine and faeces has sometimes become a serious environmental burden because of extensive use of high protein diets. Improvement of the utilization efficiency of dietary protein and reduction of $\mathrm{N}$ waste through rational formulation of diets has become very important. A considerable portion of $\mathrm{N}$ excreted in the faeces is endogenous material. Urinary $\mathrm{N}$ originates from inevitable losses related to maintenance, losses associated with the deposition of AA into skeletal muscle tissue, losses resulting from any imbalance between energy and protein supplied by the diet, and excretion of purine derivatives, degradation products of microbial 


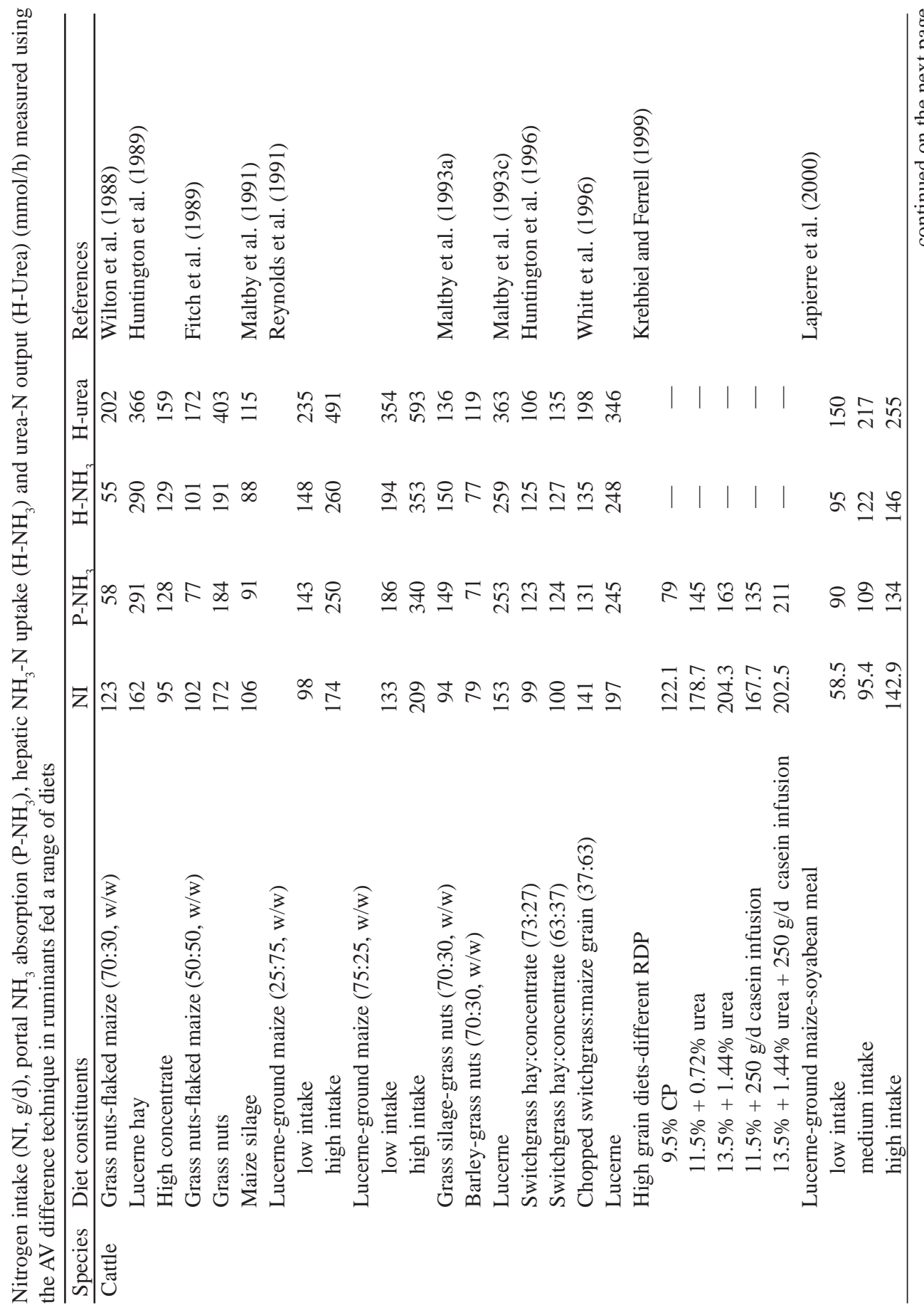


TAN Z., MURPHY M. R.

舀总

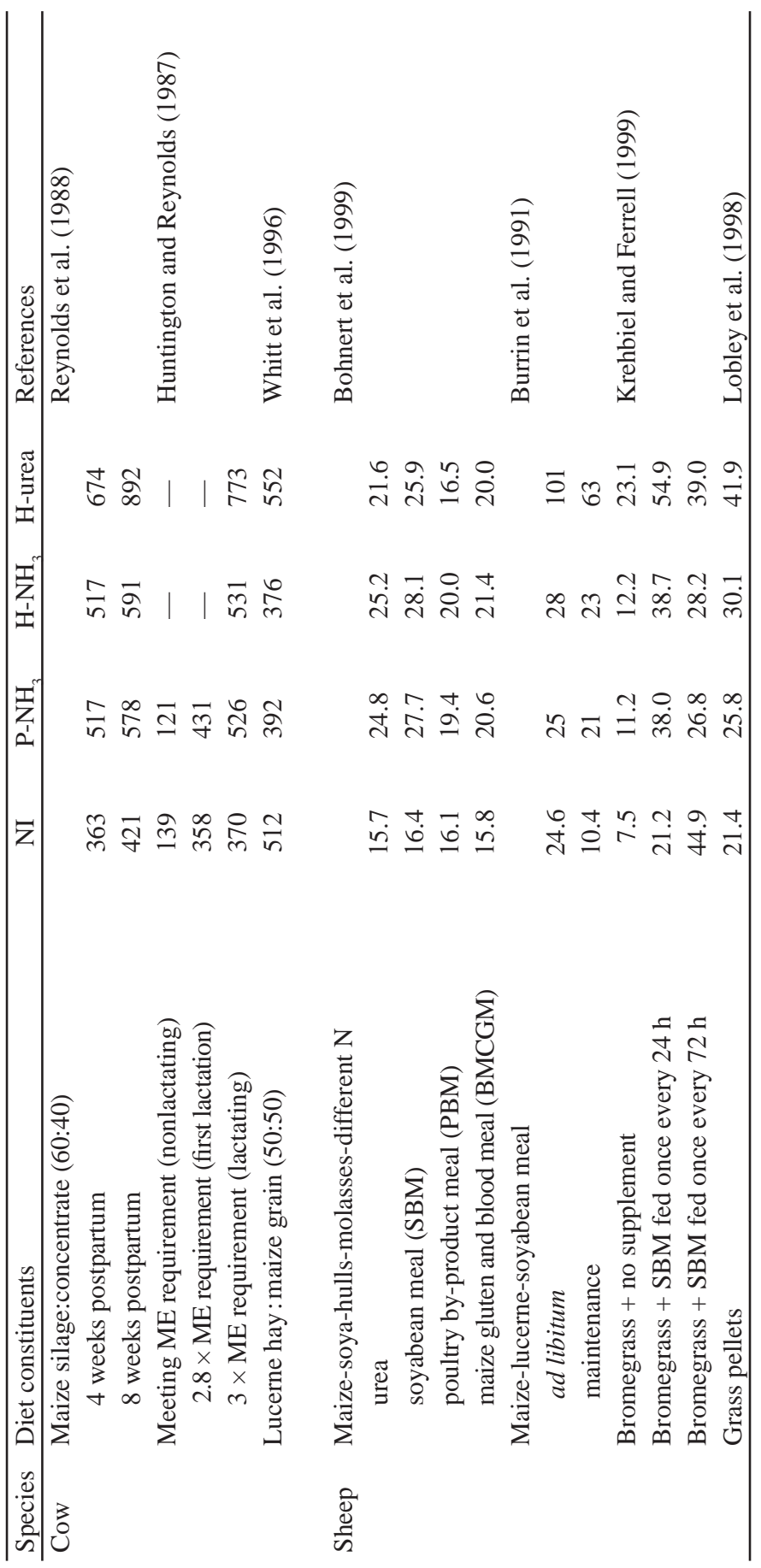


nucleic acids absorbed from the small intestine (Van Bruchem et al., 1997). Excretion of endogenous $\mathrm{N}$ is considerably higher than ileal $\mathrm{N}$ flow or the quantity eliminated in faeces. These fractions only constitute part of the total quantity of endogenous protein produced because much endogenous protein is reabsorbed. Of these routes, urea recycling is one of the most important components of endogenous protein reabsorption.

The transport of urea N into the GIT is a normal process of great significance in the physiology of all mammals. A large amount of $\mathrm{N}$ passes through the urea pool daily and this provides a potential target for manipulation to improve its conversion to animal products. There are two main directions: either reduce the amount of dietary $\mathrm{N}$ converted to urea by reducing $\mathrm{NH}_{3}$ absorption and AA catabolism, or improve the conversion of urea-N, produced in the liver and returned to the digestive tract, into microbial protein. Although many complicated relationships exist between $\mathrm{N}$ intake and hepatic urea-N (Table 1), Bunting et al. (1989) noted that net incorporation of blood urea- $\mathrm{N}$ into bacterial protein is inversely related to $\mathrm{N}$ intake; this implies that hepatic $\mathrm{NH}_{3}$ production may be reduced by manipulating dietary $\mathrm{N}$ sources. For example, a less degradable source of dietary protein may provide a greater proportion of absorbable AA entering small intestines; this can reduce urea synthesis. Krehbiel and Ferrell (1999) noted that for cattle consuming high-grain diets, an optimal amount of DIP in the diets enhanced fermentation in the rumen, increased AA flow to the duodenum, and increased net portal appearance of AA, without influencing energy use by the PDV. When the dietary DIP requirement has been met, additional DIP will not be beneficial. For example Bohnert et al. (1999) demonstrated that $\mathrm{N}$ retention and efficiency were improved by increasing UIP from 40 to $60 \%$ of total CP when lambs were fed low energy diets.

On the other hand, supplementing diets with fermentable energy sources can enhance utilization of $\mathrm{N}$ for bacterial synthesis. Huntington (1989) reported that increased intake of readily fermentable carbohydrate increased the rate of endogenous urea transfer through the rumen wall, decreased salivary transfer of urea to the rumen, and decreased urea transfer to post-ruminal tissues. Thus, MCP production in the rumen can be increased. Obitsu et al. (2000) reported that abomasal infusion of glucose reduced urea production and urinary $\mathrm{N}$ excretion. This illustrates that increased glucose absorption from the small intestine may contribute to increased flow of AA to peripheral tissues and to reduced wastage as excretion of urinary N. As described above, it is necessary to maintain a suitable ratio of available energy and $\mathrm{N}$ to improve the utilization of recycled urea.

It is well known that protozoa in the rumen increase the degradation of dietary protein, producing a rapid release of $\mathrm{NH}_{3}$. They also ingest and digest bacteria, recycling more N. Jouany (1996) concluded that defaunation may improve $\mathrm{N}$ utilization in ruminants by increasing AA supply to the intestines, by reducing 
urea synthesis, and by reducing urinary $\mathrm{N}$ excretion and bacterial $\mathrm{N}$ turnover. In addition, Koenig et al. (2000) demonstrated that defaunation improved the intraruminal metabolism of $\mathrm{N}$ by increasing both the ruminal concentration of bacteria and the flow of bacterial $\mathrm{N}$ to the intestine.

It is also possible to manipulate the utilization efficiency of recycled urea by adjusting diet structure (i.e. the forage to concentrate ratio) and intake. Huntington et al. (1996) reported that, when fed diets with $20 \%$ or less concentrate, steers recycled $90 \%$ of hepatic urea production; the percentage of recycled urea decreased to 64 with $63 \%$ of the diet as concentrates, and to $51 \%$ when diets with $90 \%$ concentrate were fed. Increased urea recycling to the GIT may improve the overall efficiency of $\mathrm{N}$ utilization for maintenance and production. Under conditions of low or zero $\mathrm{N}$ intakes, urea- $\mathrm{N}$ production exceeds $\mathrm{N}$ intake in ruminants as body protein is mobilized when animals are in negative $\mathrm{N}$ balance.

\section{FUTURE DIRECTIONS}

Much data on $\mathrm{NH}_{3}$ production, $\mathrm{NH}_{3}$ absorption, and urea recycling in ruminants has been accumulated (Table 1); however, it is still difficult to utilize these data in feeding practice because few experiments have been conducted using practical diets. In the future, we propose that nutritional manipulations of $\mathrm{N}$ utilization must be tested on, and applied to, practical diets while the database on this topic continues to grow, i.e. while the optimal nitrogen intake, the ratio of dietary nitrogen and readily fermentable carbohydrate, are determined by the slow release technique for NPN in the rumen and the bypass technique for crude protein. After obtaining these practical data, these techniques or nutritional parameters will be organically conformed and applied in the practical diets of various animals. Further, considering the complexity of urea recycling, it is necessary to integrate the effects of the many dietary factors involved and to study their dynamics. This will involve the development and refinement of mechanistic metabolic models.

\section{REFERENCES}

Al-Dehneh A., Huber J.T., Wanderley R., Theurer C.B., Pessarakli M., DeYoung D., 1997. Incorporation of recycled urea-N into ruminal bacteria flowing to the small intestine of dairy cows fed a high-grain and high-forage diet. Anim. Feed Sci. Tech. 68, 327-338

Alio A., Theurer C.B., Lozano O., Huber J.T., Swingle R.S., Delgado-Elorduy A., Cuneo P., DeYoung D., Webb K.E. Jr., 2000. Splanchnic nitrogen metabolism by growing beef steers fed diets containing sorghum grain flaked at different densities. J. Anim. Sci. 78, 1355-1363

Allan S.A., Miller E.L., 1976. Determination of nitrogen requirement for microbial growth from the effect of urea supplementation of a low $\mathrm{N}$ on abomasal $\mathrm{N}$ flow and $\mathrm{N}$ recycling in wethers and lambs. Brit. J. Nutr. 36, 353-368 
Bödeker D., Shen Y., Höller H., 1991. Influence of short chain fatty acid and $\mathrm{HCO}_{3}^{-}$on ammonia absorption through sheep rumen wall. In: Proceedings of the $3^{\text {rd }}$ International Symposium on the Nutrition of Herbivores. MSAP, University Pertanian, Serdang, Selangor (Malaysia), p. 36

Bödeker D., Shen Y., Kemkoski J., Höller H., 1992. Influence of short chain fatty acids on ammonia absorption across the rumen wall in sheep. Exp. Physiol. 77, 369-376

Bödeker D., Winkler A., Höller H., 1990. Ammonia absorption from the isolated reticulo-rumen in sheep. Exp. Physiol. 75, 587-595

Bohnert D.W., Larson B.T., Lewis S.J., Richards C.J., Swanson K.C., Harmon D.L., Mitchell G.E. Jr., 1999. Net nutrient flux in visceral tissues of lambs fed diets differing in supplemental nitrogen source. J. Anim. Sci. 77, 2545-2553

Bunting L.D., Boling J.A., MacKown C.T., 1989. Effect of dietary protein level on nitrogen metabolism in the growing bovine: I. Nitrogen recycling and intestinal protein supply in calves. J. Anim. Sci. 67, 810-819

Burrin D.G., Ferrell C.L., Eisemann J.H., Britton A., 1991. Level of nutrition and splanchnic metabolic flux in young lambs. J. Anim. Sci. 69, 1082-1091

Firkins J.L, Lewis S.M., Montgomery L., Berger L.L., Merchen N.R., Fahey G.C., 1987. Effect of feed intake and dietary urea concentration on ruminal dilution rate and efficiency of bacteria growth in steers. J. Dairy Sci. 70, 2312-2321

Fitch N.A., Gill M., Lomax M.A., Beever D.E., 1989. Nitrogen and glucose metabolism by the liver of forage- and forage-concentrate fed cattle. Proc. Nutr. Soc. 48, 76A

Haussinger D., Lamers W.H., Moorman A.F.M., 1992. Hepatocyte heterogeneity in the metabolism of amino acids and ammonia. Enzyme 46, 72-93

Havassy I., Kowalczyk J., Horský K., Košta K., Otwinowska A., 1982. Incorporation of ${ }^{15} \mathrm{~N}$-urea into individual amino acids of rumen bacteria and blood plasma protein in sheep. Acta Physiol. Pol. 33, 415-419

Huntington G.B., 1989. Hepatic urea synthesis and site and rate of urea removal from blood of beef steers fed alfalfa hay or a high concentrate diet. Can. J. Anim. Sci. 69, 215-223

Huntington G.B., Reynolds C.K., 1986. Blood flow and nutrient flux across stomach and post-stomach of steers. Fed. Proc. 45, 606

Huntington G.B., Reynolds C.K., 1987. Oxygen consumption and metabolite flux of bovine portaldrained viscera and liver. J. Nutr. 117, 1167-1173

Huntington G.B., Reynolds C.K., Stroud B.H., 1989. Techniques for measuring blood flow in splanchnic tissues of cattle. J. Dairy Sci. 72, 1583-1595

Huntington G.B., Zetina E.J., Whitt J. M., Potts W., 1996. Effects of dietary concentrate level on nutrient absorption, liver metabolism, and urea kinetics of beef steers fed isonitrogenous and isoenergetic diets. J. Anim. Sci. 74, 908-916

Jackson A.A., 1995. Salvage of urea-nitrogen and protein requirements. Proc. Nutr. Soc. 54, 535-547

Jouany J.P., 1996. Effect of rumen protozoa on nitrogen utilization by ruminants. J. Nutr. 126, 1335S-1346S

Kennedy P.M., Milligan L.P., 1980. The degradation and utilization of endogenous urea in the gastrointestinal tract of ruminants: a review. Can. J. Anim. Sci. 60, 205-221

Koenig K.M, Newbold C.J., McIntosh F.M., Rode L.M., 2000. Effects of protozoa on bacterial nitrogen recycling in the rumen. J. Anim. Sci. 78, 2431-2445

Kowalczyk J., Havassy I., Košta K., Otwinowska A., 1975a. Incorporation of nitrogen from intravenously administrated ${ }^{15} \mathrm{~N}$ labeled urea into the bacterial protein in the sheep. Acta Physiol. Pol. 25, 308-312

Kowalczyk J., Havassy I., Košta K., Otwinowska A., 1982. Utilization of urea ${ }^{15} \mathrm{~N}$ for the synthesis of the rumen microorganisms and blood plasma protein in sheep. Acta Physiol. Pol. 33, 23-28 
Kowalczyk J., Havassy I., Otwinowska A., Košta K., 1975b. Passage of the intravenously administered ${ }^{15} \mathrm{~N}$ urea into the digestive tract and its excretion in the sheep. Acta Physiol. Pol. 26, 299-306

Krehbiel C.R., Ferrell C.L., 1999. Effects of increasing ruminally degradable nitrogen and abomasal casein infusion on net portal flux of nutrients in yearling heifers consuming a high-grain diet. J. Anim. Sci. 77, 1295-1305

Lapierre H., Bernier J.F., Dubreuil P., Reynolds C.K., Farmer C., Ouellet D.R., Lobley G.E., 2000. The effect of feed intake level on splanchnic metabolism in growing beef steers. J. Anim. Sci. 78, 1084-1099

Leng R.A., Nolan J.V., 1984. Nitrogen metabolism in the rumen. J. Dairy Sci. 67, 1072-1089

Li Pun H.H., Satter L.D., 1975. Nitrogen fixation in ruminants. J. Anim. Sci. 41, 1161-1163

Lobley G.E., Bremner D.M., Nieto R., Obitsu T., Hotston Moore A., Brown D.S., 1998. Transfers of metabolites across the ovine liver in response to short-term infusions of an amino acid mixture into the mesenteric vein. Brit. J. Nutr. 80, 371-379

Lobley G.E., Connell A., Lomax M.A., Brown D.S., Milne E., Calder A.G., Farningham D.A.H., 1995. Hepatic detoxification of ammonia in the ovine liver: possible consequences for amino acid catabolism. Brit. J. Nutr. 73, 667-685

Maltby S.A., Beever D.E., Lomax M.A., Crompton L.A., Pippard C.J., 1993a. The influence of diet and increased ammonia supply on energy and nitrogen metabolism across splanchnic tissues in growing cattle. Anim. Prod. 56, 431 (Abstr.)

Maltby S.A., Crompton L.A., Lomax M.A., Beever D.E., Pippard C.J., 1993b. The effect of increased ammonia supply on post-prandial hepatic metabolism in growing steers fed either forage or cereal based diets. Proc. Nutr. Soc. 52, 295A

Maltby S.A., Lomax M.A., Beever D.E., Pippard C.J., 1991. The effect of increased ammonia supply on post-prandial portal-drained viscera and hepatic metabolism in growing steers fed maize silage. In: C. Wenk, M. Boessinger (Editors). Energy Metabolism of Farm Animals. EAAP Publication No. 58, pp. 20-23

Maltby S.A., Reynolds C.K., Lomax M.A., Beever D.E., 1993c., The effect of increased absorption of ammonia and arginine on splanchnic metabolism of beef steers. Anim. Prod. 56, 462-463

Newbold C.J., Teferedegne B., Kim H-S., Zuur G., Lobley G.E., 2000. Effects of protozoa on nitrogen metabolism in the rumen of sheep. Reprod. Nutr. Develop. 40, 189-228

Nolan J.V., 1975. Quantitative models of nitrogen metabolism in sheep. In: I.W. McDonald, A.C.I. Warner (Editors). Digestion and Metabolism in the Ruminant. University of New England Publ. Unit, Armidale (Australia), pp. 416-431

Nolan J.V., Leng R.A., 1972. Dynamic aspects of ammonia and urea metabolism in sheep. Brit. J. Nutr. 27, 177-194

Nolan J.V., MacRae J.C., 1976. Absorption and recycling of nitrogenous compounds in the digestive tract of sheep. Proc. Nutr. Soc. 35, 110A

Nolan J.V., Stachiw S., 1979. Fermentation and nitrogen dynamics in Merino sheep given a lowquality-roughage diet. Brit. J. Nutr. 42, 63-80

Norton B.W., Murray R.M., Entwistle K.W., Nolan J.V., Ball F.M., Leng R.A., 1978. The nitrogen metabolism of sheep consuming Flinders grass (Iseilema spp.), Mitchell grass (Astrebla spp.) and mixed native pasture. Aust. J. Agr. Res. 29, 595-603

Obitsu T., Bremner D., Milne E., Lobley G.E., 2000. Effect of abomasal glucose on alanine metabolism and urea production in sheep. Brit. J. Nutr. 84, 157-163

Parker D.S., Lomax M.A., Seal C.J., Wilton J.C., 1995. Metabolic implications of ammonia production in the ruminant. Proc. Nutr. Soc. 54, 549-563

Rémésy C., Demigné C., 1989. Specific effects of fermentable carbohydrates on blood urea flux and ammonia absorption in the rat cecum. J. Nutr. 119, 560-565 
Rémond D., Chaise J.P., Delval E., Poncet C., 1993. Net transfer of urea and ammonia across the ruminal wall of sheep. J. Anim. Sci. 71, 2785-2792

Reynolds C.K., 1992. Metabolism of nitrogenous compounds by ruminant liver. J. Nutr. 122, 850854.

Reynolds C.K., Huntington G.B., Tyrrell H.F., Reynolds P.J., 1988. Net portal-drained visceral and hepatic metabolism of glucose, L-lactate, and nitrogenous compounds in lactating cows. J. Dairy Sci. 71, 1803-1812

Reynolds C.K., Tyrell H.F., Reynolds P.J., 1991. Effect of diet forage-to-concentrate ratio and intake on energy metabolism in growing beef heifers: net nutrient metabolism by visceral tissues. J. Nutr. 121, 1004-1015

Sandek A., Krawielitzki K., Kowalczyk J., Kreienbring F., Gabel M., Schönhusen U., Żebrowska T., Hagemeister H., Voigt J., 2002. Studies on N-metabolism in different gastrointestinal sections of sheep using the digesta exchange technique. 3. N secretion and reabsorption. J. Anim. Feed Sci. 11, 277-288

Sarraseca A., Milne E., Metcalf M.J., Lobley G.E., 1998. Urea recycling in sheep: effects of intake. Brit. J. Nutr. 79, 79-88

Seal C.J., Reynolds C.K., 1993. Nutritional implications of gastrointestinal and liver in ruminants. Nutr. Res. Rev. 6, 185-208

Siddons R.C., Nolan J.V., Beever D.E., MacRae J.C., 1985. Nitrogen digestion and metabolism in sheep consuming diets containing contrasting forms and levels of N. Brit. J. Nutr. 54, 175-187

Song M.K., Kennedy J.J., 1989. Effects of ammoniated barley silage on ruminal fermentation, nitrogen supply to the small intestine, ruminal and whole tract digestion, and milk production of Holstein cows. J. Dairy Sci. 72, 2981-2990

Symonds H.W., Mather D.L., Collis K.A., 1981. The maximum capacity of the liver of the adult dairy cow to metabolize ammonia. Brit. J. Nutr. 46, 481-486

Van Bruchem J., Voigt J., Lammers T.S.C., Wienhoven W., Schönhusen U., Ketelaars J.J.M.H., Tamminga S., 1997. Secretion and reabsorption of endogenous protein along the small intestine of sheep: estimates derived from ${ }^{15} \mathrm{~N}$ dilution of plasma non-protein-N. Brit. J. Nutr. 77, 273-286

Whitt J., Huntington G., Zetina E., Casse E., Taniguchi K., Potts W., 1996. Plasma flow and net nutrient flux across gut and liver of cattle fed twice daily. J. Anim. Sci. 74, 2450-2461

Wilton J.C., Gill M., Lomax M.A., 1988. Uptake of ammonia across the liver of forage-fed cattle. Proc. Nutr. Soc. 47, 153A

\section{STRESZCZENIE}

\section{Produkcja i wchłanianie amoniaku oraz recyrkulacja mocznika u przeżuwaczy. Praca przeglądowa}

Omówiono ważniejsze badania dotyczące produkcji i wchłaniania amoniaku oraz recyrkulacji mocznika u przeżuwaczy. Opisano produkcję i wykorzystanie amoniaku w żwaczu i dalszej części przewodu pokarmowego. Przedyskutowano zagadnienie wchłaniania amoniaku do krwi żyły wrotnej, detoksyzację amoniaku i syntezę mocznika w wątrobie oraz rozkład mocznika w przewodzie pokarmowym. Analizowano czynniki wpływające na recyrkulację mocznika i jego szlaki. Sugeruje się, że dalsze badania powinny być ukierunkowane na dynamikę recyrkulacji mocznika i poprawę konwersji białka oraz opracowanie zintegrowanego mechanistycznego modelu opisującego procesy trawienia i metabolizmu składników azotowych u przeżuwaczy żywionych typowymi dietami. 